\title{
Differential Effects of Synaptic and Extrasynaptic NMDA Receptors on $A \beta$-Induced Nitric Oxide Production in Cerebrocortical Neurons
}

\author{
Elena Molokanova, Mohd Waseem Akhtar, Sara Sanz-Blasco, Shichun Tu, Juan C. Piña-Crespo, Scott R. McKercher, \\ and Stuart A. Lipton \\ Del E. Webb Center for Neuroscience, Aging, and Stem Cell Research, Sanford-Burnham Medical Research Institute, La Jolla, California 92037
}

\begin{abstract}
Oligomerized amyloid- $\beta(\mathrm{A} \beta)$ peptide is thought to contribute to synaptic damage, resulting in dysfunctional neuronal networks in patients with Alzheimer's disease. It has been previously suggested that $\mathrm{A} \beta$ may be detrimental to neuronal health, at least in part, by triggering oxidative/nitrosative stress. However, the mechanisms underlying this process remain to be elucidated. Here, using rat primary cerebrocortical cultures, we demonstrate that $\mathrm{A} \beta_{1-42}$ oligomers trigger a dramatic increase in intracellular nitric oxide (NO) concentration via a process mediated by activation of NMDA-type glutamate receptors (NMDARs). Considering that synaptic NMDARs and extrasynaptic NMDARs (eNMDARs) can have opposite effects on neuronal viability, we explored their respective roles in A $\beta$-induced increases in NO levels. Surprisingly, after pharmacological isolation of eNMDARs, we discovered that eNMDARs are primarily responsible for the increase in neuronal NO triggered by A $\beta$ oligomers. Moreover, we found that the eNMDAR-mediated increase in NO can produce S-nitrosylation of Drp1 (dynamin-related protein 1) and Cdk5 (cyclin-dependent kinase 5), targets known to contribute to $\mathrm{A} \beta$-induced synaptic damage. These results suggest that pharmacological intervention specifically aimed at eNMDARs may decrease $\mathrm{A} \beta$-induced nitrosative stress and thus ameliorate neurotoxic damage to synapses.
\end{abstract}

Key words: amyloid- $\beta$; extrasynaptic; nitric oxide; NMDA receptor; synaptic

\section{Introduction}

Alzheimer's disease $(\mathrm{AD})$ causes degeneration and dysfunction of synapses and neurons, predominantly in the hippocampus and cerebrocortex. Amyloid- $\beta$ (A $\beta$ ) oligomers are thought to contribute to $\mathrm{AD}$ by affecting a number of intracellular signaling pathways. In this study, we explore a mechanistic link among oligomeric $\mathrm{A} \beta$ peptide, extrasynaptic NMDAR (eNMDAR) activation, and excessive production of nitric oxide (NO).

During progression of $\mathrm{AD}$, neurons exhibit several pathological features, including increased oxidative/nitrosative stress, accumulation of misfolded proteins, mitochondrial dysfunction, synaptic loss, and eventually cell death (Butterfield et al., 2001; Selkoe, 2002; Palop and Mucke, 2010; Nakamura et al., 2013). In addition, glutamate excitotoxicity, principally representing ex-

Received July 8, 2013; revised Jan. 31, 2014; accepted March 1, 2014.

Author contributions: E.M. and S.A.L. designed research; E.M., M.W.A., S.S.-B., S.T., and J.C.P.-C. performed research; E.M. and M.W.A. analyzed data; E.M., S.R.M., and S.A.L. wrote the paper.

This work was supported by National Institutes of Health Grants P01 HD29587, P01 ES016738, and P30 NS076411 (to S.A.L.). We thank Traci Fang Newmeyer for excellent technical assistance.

S.A.L. discloses that he is the discoverer and named inventor on worldwide patents for the use of memantine in neurodegenerative disorders, and participates in a royalty-sharing agreement with Harvard Medical School/Boston's Children's Hospital for licensing these patents to Forest Laboratories, New York, NY. The other authors declare no competing financial interests.

Correspondence should be addressed to either Elena Molokanova or Stuart A. Lipton, Del E. Webb Center for Neuroscience, Aging, and Stem Cell Research, Sanford-Burnham Medical Research Institute, La Jolla, California 92037.E-mail: emolokanova@hotmail.com or slipton@sanfordburnham.org.

DOI:10.1523/JNEUROSCI.2907-13.2014

Copyright $\odot 2014$ the authors $\quad 0270-6474 / 14 / 345023-06 \$ 15.00 / 0$ cessive activation of NMDARs, can lead to increased $\mathrm{Ca}^{2+}$ influx, subsequent overstimulation of calcium-regulated intracellular pathways, and overload of intracellular calcium stores (Lau and Tymianski, 2010). Recently, further mechanistic details related to glutamate overstimulation have been reported. Namely, changes in the activation pattern of NMDARs at different subcellular locations have been proposed as critical in activating pathways leading to neuroprotection versus neurodestruction (Hardingham and Bading, 2010). Generally, physiological activation of synaptic NMDARs (sNMDARs) tends to be neuroprotective via engagement of multiple pathways that enhance antioxidant defenses (Papadia et al., 2008), nuclear signaling to cAMP response elementbinding protein (Hardingham et al., 2002), and signaling by extracellular signal-regulated kinase 1/2 (Ivanov et al., 2006). In contrast, eNMDAR activity can initiate signaling cascades leading to neuronal damage by shutting off prosurvival pathways (Hardingham et al., 2002), activating synaptic injury and proapoptotic molecules (Talantova et al., 2013), enhancing neuronal cyclo-oxygnease 2 expression (Stark and Bazan, 2011), and mediating taudependent neurodegeneration (Tackenberg et al., 2013).

Under physiological conditions, the most active NMDAR subpopulation appears to be composed of sNMDARs, which ensures normal synaptic neurotransmission and promotes neuronal survival. Often during pathological events, however, this pattern is disrupted by reduction of sNMDAR activity, augmentation of eNMDAR activity, or both (Hardingham and Bading, 2010). 
A

\section{Before oligomeric $A \beta_{1-42}$}

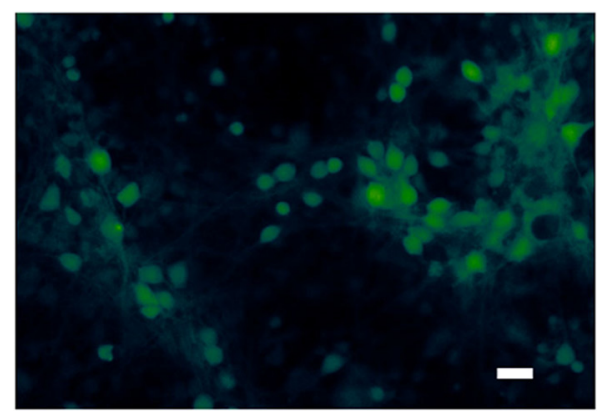

After 20 min exposure to oligomeric $A \beta_{1-42}$

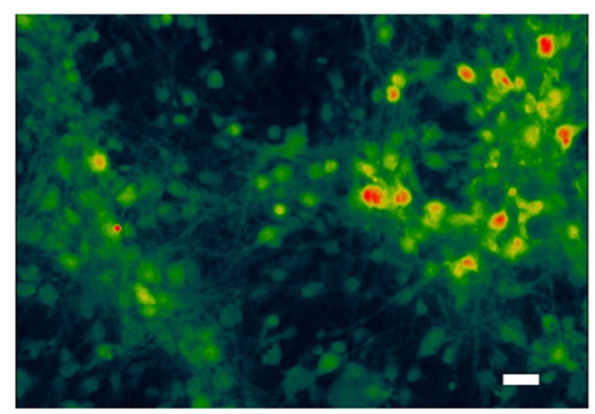

B
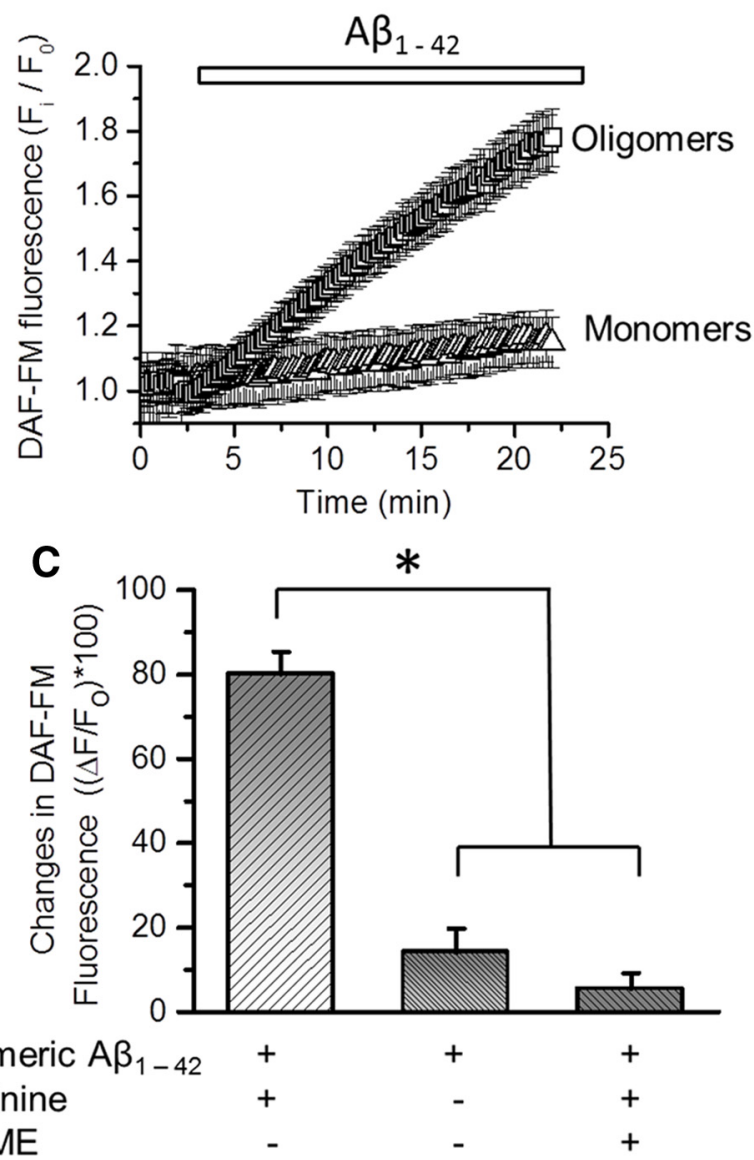

Figure 1. N0 production in cerebrocortical neurons in response to exposure to $A \beta_{1-42}$ peptide. $A$, Representative pseudocolor images of DAF-FM diacetate-labeled cells before and after 20 min exposure to $250 \mathrm{~nm}$ oligomeric $A \beta_{1-42}$. "Warmer" colors in these images reflect higher DAF-FM fluorescence, which corresponds to higher N0 levels. Scale bar, $10 \mu \mathrm{m}$. $\boldsymbol{B}$, Time course of changes in DAF-FM fluorescence intensity in the presence of $250 \mathrm{~nm}$ oligomeric $A \beta_{1-42}$ or $1 \mu \mathrm{m}$ monomeric $A \beta_{1-42}$. C, Summary of changes in DAF-FM fluorescence intensity after a 20 min exposure to $250 \mathrm{~nm}$ oligomeric $A \beta_{1-42}$ in the presence or absence of $500 \mu \mathrm{m}$ L-arginine and $1 \mathrm{~mm}$ L-NAME. Values represent the mean \pm SEM ( ${ }^{*} p<0.001, n \geq 50$ neurons for each condition).

In this study, we found that exposure to $\mathrm{A} \beta$ oligomers leads to a dramatic increase in the production of $\mathrm{NO}$ in cerebrocortical neurons. Furthermore, we determined that the majority of this $\mathrm{A} \beta$-triggered NO increase is mediated by eNMDARs rather than sNMDARs, as previously thought. This effect likely results from the ability of $\mathrm{A} \beta$ oligomers to alter the balance of glutamatergic activity between sNMDARs and eNMDARs, as recently reported (Talantova et al., 2013). Considering the pronounced role of eNMDARs in neuronal pathophysiology, the effect of this excessive increase in $\mathrm{NO}$ could affect various proteins crucial for neuronal survival. Moreover, our results may point to new targets for pharmacological intervention to prevent or slow the progression of $\mathrm{AD}$.

\section{Materials and Methods}

Cell cultures. Cerebrocortical cultures were derived from embryonic day 17 Sprague Dawley rats. Following enzymatic treatment (papain, $200 \mathrm{U} / \mathrm{ml} ; 30 \mathrm{~min}, 37^{\circ} \mathrm{C}$ ) and mechanical dissociation of cortices in minimum essential medium (MEM, Invitrogen), cells were plated on poly-L-lysine-coated glass coverslips in DMEM with Ham's F12 and heat-inactivated iron-supplemented calf serum (HyClone) at a ratio of 8:1:1. Cells were grown to $50 \%$ confluence at $37^{\circ} \mathrm{C}$ in a humidified $5 \%$ $\mathrm{CO}_{2} / 95 \%$ air atmosphere.

Preparation of $A \beta$ peptide. Human synthetic $\mathrm{A} \beta_{1-42}$ (Anaspec) and scrambled $\mathrm{A} \beta_{1-42}$ (GenicBio) were dissolved following established procedures (Talantova et al., 2013). Briefly, peptide was suspended at $1 \mathrm{~mm}$ in hexafluoroisopropanol (HFIP; J.T. Baker) and incubated for $2 \mathrm{~h}$ at room temperature. HFIP was evaporated by vacuum centrifugation, and peptide was resuspended at $5 \mathrm{~mm}$ in dry DMSO (ATCC). Monomers were frozen at this step and stored at $-80^{\circ} \mathrm{C}$. For oligomerization, $\mathrm{A} \beta_{1-42}$ peptide was dissolved using MEM (Invitrogen) to $500 \mu \mathrm{M}$, incubated at $4^{\circ} \mathrm{C}$ for at least $24 \mathrm{~h}$, and sonicated for $10 \mathrm{~min}$ before use. Total concentration of $\mathrm{A} \beta_{1-42}$ was monitored by ELISA after centrifugation at $11,000 \times g$ for 2 min. $A \beta$ peptides were diluted in physiological buffer for experiments.

Fluorescent measurements of NO changes. To detect intracellular NO, we used 4-amino-5-methylamino-2', $7^{\prime}$-difluorofluorescein diacetate (DAF-FM diacetate; Life Technologies). Primary cerebrocortical cells (14-21 d in vitro) were loaded according to the manufacturer's protocol with 2.5-5 $\mu$ M DAF-FM diacetate in loading buffer (132 mм NaCl, 4.2 mм KCl, $1.8 \mathrm{~mm} \mathrm{CaCl}_{2}$, 5 mm D-glucose, 10 mm HEPES, pH 7.4). Then cells were thoroughly washed and left at room temperature for $15 \mathrm{~min}$ for complete de-esterification of the probe. Imaging buffer was supplemented with $500 \mu \mathrm{M}$ L-arginine. Time-lapse images were acquired every $10 \mathrm{~s}$ for $25 \mathrm{~min}$ by CCD camera (Sensicam, Cooke) on a Zeiss Axiovert $100 \mathrm{M}$ microscope equipped with a fluorescein filter set (excitation, $485 / 20 \mathrm{~nm}$; emission, 525/30 nm). Acquisition and analyses were performed with SlideBook 5.0 software (Intelligent Imaging Innovations). Fluorescence intensity was measured over entire cell bodies, and responses were presented as arbitrary units or calculated as changes in fluorescence ratio $\Delta F / F_{0}$, where $F_{0}$ is the baseline and $\Delta F$ is the fluorescence change from the baseline.

Pharmacological isolation of eNMDARs. To pharmacologically isolate eNMDARs, we initially activated sNMDARs by brief $(\sim 5 \mathrm{~min})$ application of bicuculline $(50 \mu \mathrm{M})$ to decrease inhibitory input, and then blocked sNMDARs by $15 \mathrm{~min}$ incubation in the essentially irreversible 


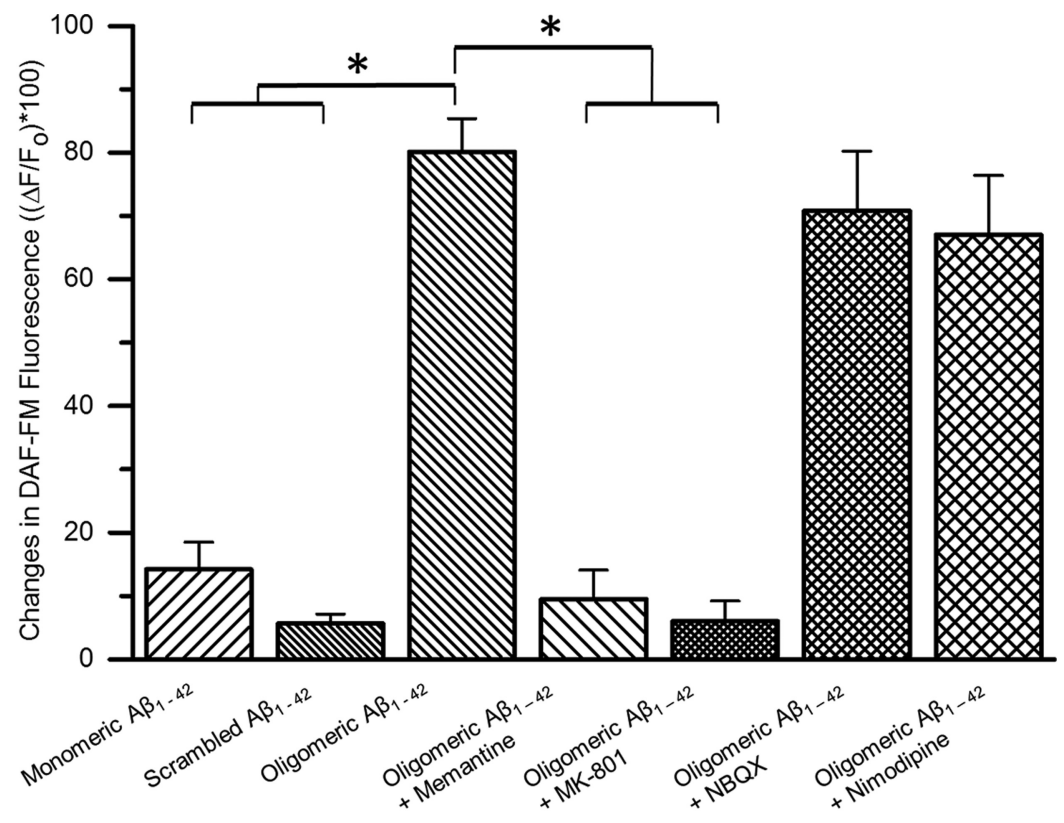

Figure 2. NMDARs mediate oligomeric $A \beta_{1-42}$-induced changes in NO levels. Summary of changes in DAF-FM fluorescence intensity after a 20 min exposure to $1 \mu \mathrm{m}$ monomeric $A \beta_{1-42}, 250 \mathrm{~nm}$ scrambled $A \beta_{1-42}$, or $250 \mathrm{~nm}$ oligomeric $A \beta_{1-42}$ either alone or in combination with different pharmacological inhibitors. Values represent the mean $\pm \mathrm{SEM}\left({ }^{*} p<0.001, n \geq 30\right.$ neurons for each condition).

NMDAR inhibitor MK-801 (10 $\mu$ m; Hardingham et al., 2002; Okamoto et al., 2009). After washing out bicuculline and MK-801, A $\beta$ peptides were added to elicit eNMDAR-dependent signaling.

Biotin switch assay of S-nitrosylated proteins. S-nitrosylated proteins were detected by biotin switch assay as previously described (Jaffrey et al., 2001; Qu et al., 2011). Briefly, cells were exposed to $250 \mathrm{~nm} \mathrm{~A} \beta$ oligomers for $60 \mathrm{~min}$ after pharmacological isolation of eNMDARs. Then, following preparation of cell lysates in $1 \%$ Triton X-100 in HEN buffer $(250 \mathrm{~mm}$ HEPES, $1 \mathrm{~mm}$ EDTA, $0.1 \mathrm{~mm}$ neocuproine), existing free thiols were blocked by $10 \mathrm{~mm}$ methyl-methanethiosulfonate (MMTS) in HEN buffer during a $20 \mathrm{~min}$ incubation at $50^{\circ} \mathrm{C}$. Proteins were precipitated with acetone to remove excess MMTS and resuspended in HEN buffer with $1 \%$ SDS. S-nitrosothiols were first selectively reduced to thiols by 20 $\mathrm{mm}$ ascorbate and then tagged with $1 \mathrm{~mm}$ sulfhydryl-specific biotinylating reagent biotin-HPDP (Pierce). The biotinylated proteins were pulled down with NeutrAvidin-Agarose beads (Pierce) and analyzed by immunoblotting.

Statistical analysis. We used Student's $t$ test for two-way comparisons and ANOVA with Tukey's post hoc HSD test for multiple comparisons. Results are expressed as the mean \pm SEM.

\section{Results}

We compared the levels of NO in cortical neurons under control conditions and during the exposure to $\mathrm{A} \beta$ peptides in monomeric, oligomeric, or scrambled form. Control neurons in our cultures exhibited spontaneous synchronous electrical activity, indicative of healthy synaptic transmission in neuronal networks in vitro. Here we observed only modest increases in intracellular NO levels over time, suggesting that the production and consumption of NO were in balance during spontaneous, synaptically driven physiological activity. On the other hand, the application of $250 \mathrm{~nm}$ oligomeric $\mathrm{A} \beta_{1-42}$ triggered a rapid surge in $\mathrm{NO}$ levels, resulting in dramatic increases in intracellular $\mathrm{NO}$ levels after a 20 min exposure (Fig. 1). Representative images (Fig. $1 A$ ) of neurons labeled with DAF-FM diacetate, a fluorescent NO indicator, demonstrate that the majority of neurons responded to $\mathrm{A} \beta_{1-42}$ oligomers by increasing NO. In contrast, neither monomeric nor scrambled $\mathrm{A} \beta_{1-42}$ induced significant changes in $\mathrm{NO}$ levels (Figs. 1B, 2). NO in neurons is produced predominantly by neuronal NO synthase (nNOS), an enzyme that catalyzes the generation of $\mathrm{NO}$ from L-arginine and oxygen (Groves and Wang, 2000). Elimination of L-arginine from the extracellular solution in our experiments abrogated the oligomeric $\mathrm{A} \beta$-induced rise in NO levels, consistent with the notion that the observed increase is a consequence of NOS activity. This conclusion was strengthened by our finding that the addition of $1 \mathrm{~mm} \mathrm{~N}$ - $\omega$-nitro-L-arginine methyl ester (L-NAME), a NOS inhibitor, completely eliminated the increase in NO production triggered by oligomeric $\mathrm{A} \beta_{1-42}$ (Fig. 1C).

Since (1) activity of nNOS is calcium dependent, (2) NMDARs exhibit high calcium permeability, and (3) A $\beta$ oligomers have been implicated in adverse effects on glutamatergic signaling in the brain, we investigated whether NMDARs mediate $\mathrm{A} \beta$-triggered NO production in cortical neurons. We found that the application of specific NMDAR antagonists MK-801 or memantine $(10 \mu \mathrm{M})$ during the exposure of neurons to $250 \mathrm{~nm}$ oligomeric $\mathrm{A} \beta_{1-42}$ dramatically diminished $\mathrm{A} \beta$-induced increases in intracellular NO. Furthermore, $25 \mu \mathrm{M}$ NBQX, a specific AMPA-type glutamate receptor antagonist, and $1 \mu \mathrm{M}$ nimodipine, an L-type calcium channel antagonist, had no effect on the rate of $A \beta$-triggered NO production (Fig. 2). Together, these results suggest that NMDARs are primarily responsible for mediating the effects of $\mathrm{A} \beta$ oligomers on $\mathrm{NO}$ production in neurons.

Recent studies have revealed that, due to their different subcellular locations, sNMDARs and eNMDARs may play disparate or even opposing roles in physiological and pathological events (Hardingham et al., 2002; Okamoto et al., 2009; Kaufman et al., 2012; Talantova et al., 2013). To assess the relative contributions of synaptic versus extrasynaptic subpopulations of NMDARs to $\mathrm{A} \beta$-induced NO production, we executed an established protocol for pharmacological isolation of eNMDARs (Hardingham et al., 2002; Okamoto et al., 2009). This protocol allows specific block of sNMDARs using a cocktail of inhibitors for GABA and NMDA receptors (see Materials and Methods), and leaves eNMDARs unaffected and thus still available for subsequent activation.

Using this protocol, we compared the effects of oligomeric $\mathrm{A} \beta_{1-42}$ on NO production mediated by either the global pool of NMDARs (sNMDARs plus eNMDARs; i.e., no pretreatment) or exclusively by eNMDARs (i.e., after pretreatment with bicuculline and MK-801). After establishing the baseline level for $2 \mathrm{~min}$, we applied $250 \mathrm{nM}$ oligomeric $\mathrm{A} \beta_{1-42}$ for 20 min while continuously monitoring changes in NO levels via quantitative DAF-FM fluorescence. Fluorescent signal traces from individual neurons demonstrate the time course of $\mathrm{A} \beta_{1-42}$-induced $\mathrm{NO}$ production mediated by the total NMDAR pool (Fig. $3 A$ ) or eNMDARs alone (Fig. $3 B$ ). Quantification of NO changes in individual cells not subjected to pharmacological pretreatment revealed that during the 20 min $\mathrm{A} \beta_{1-42}$ exposure $\mathrm{NO}$ increased $80.1 \pm$ $5.2 \%(n>200)$. In comparison, when only eNMDARs were active after pharmacological isolation, NO levels increased 
$58.6 \pm 3.9 \%(n>200$; Fig. $3 C)$, meaning that eNMDARs were responsible for $\sim 75 \%$ of global NO production mediated by all NMDARs. As a control, scrambled $\mathrm{A} \beta_{1-42}$ did not trigger changes in $\mathrm{NO}$, regardless of whether only eNMDARs or all NMDARs were functional.

To investigate potential downstream effects of eNMDAR-mediated NO production, we performed the biotin switch assay to evaluate $S$-nitrosylated proteins known to be effectors of $\mathrm{A} \beta$-induced synaptic damage [i.e., Drp1 (dynaminrelated protein 1) and Cdk5 (cyclindependent kinase 5); Cho et al., 2009; Qu et al., 2011; Nakamura et al., 2013]. Accordingly, we exposed cerebrocortical cultures to $250 \mathrm{nM}$ oligomeric $\mathrm{A} \beta_{1-42}$ for $1 \mathrm{~h}$ following pharmacological isolation of eNMDARs, and then evaluated the nitrosylation status of the proteins. We found that oligomeric $A \beta$ induced robust S-nitrosylation of Drp1 and Cdk5; as a control, scrambled $\mathrm{A} \beta$ had no effect on nitrosylation (Fig. 3D). Together, these results show that oligomeric $\mathrm{A} \beta$-induced S-nitrosylation of Drp1 and Cdk5 can be mediated by eNMDARs.

In summary, we demonstrated in cerebrocortical neurons that $\mathrm{A} \beta$ oligomers can trigger excessive production of intracellular $\mathrm{NO}$ and subsequent S-nitrosylation of downstream targets, predominantly via eNMDARs.

\section{Discussion}

$\mathrm{AD}$ is an incurable neurodegenerative disease characterized by selective damage of brain regions and neural circuits critical for memory, language, and cognition. A neuropathological hallmark of $\mathrm{AD}$ is extracellular plaques of $\mathrm{A} \beta$ aggregates. Pathologically, soluble oligomeric $A \beta$ is thought to disrupt the balance of functional activity of neuronal networks and trigger signaling pathways leading to synaptic loss, disintegration of networks, and, ultimately, failure of neurological function (Palop and Mucke, 2010; Talantova et al., 2013).

Although downstream mechanisms of detrimental effects of $\mathrm{A} \beta$ oligomers are very diverse, oxidative/nitrosative stress appears to be a major contributor to AD pathology (Cho et al., 2009; Mangialasche et al., 2009; Nakamura et al., 2013). This idea is supported by findings that $\mathrm{A} \beta$ oligomers act as a potent generator of excessive reactive oxygen and reactive nitrogen species (Keil et al., 2004). While low physiological concentrations of NO are neuroprotective (Lipton et al., 1993), pathologically high NO levels can be detrimental to neurons via a variety of reactions, including aberrant S-nitrosylation of proteins and formation of toxic peroxynitrite (Dawson et al., 1991; Lipton et al., 1993; Choi et al., 2000; Hess et al., 2005). These NO-mediated reactions can lead to mitochondrial dysfunction with resulting synaptic damage due to energy disruption, or to accumulation of misfolded proteins and their aggregates, processes known to occur in $\mathrm{AD}$ and other neurodegenerative diseases (Nakamura et al., 2013).

In this study, our goal was to elucidate the link between effects of oligomeric $\mathrm{A} \beta$ peptide and nitrosative stress in cerebrocortical
B
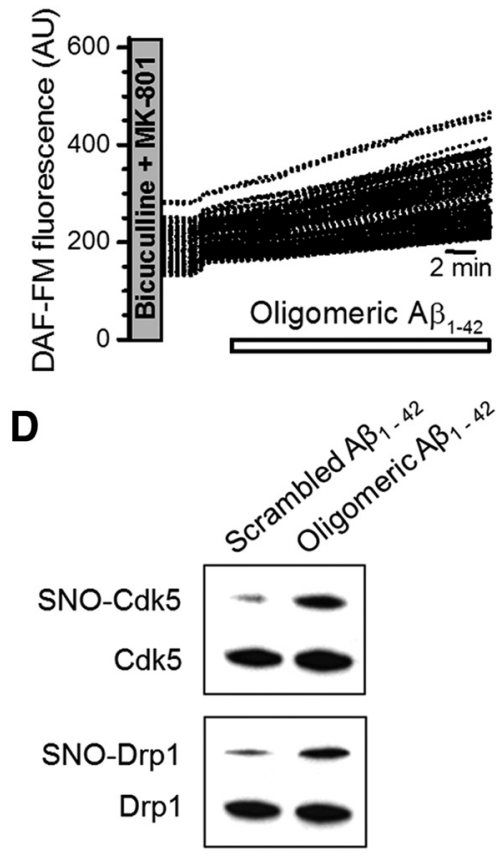

Figure 3. Oligomeric $A \beta_{1-42}$ induced changes in N0 levels are predominantly mediated by eNMDARs. $A, B$, Time course of changes in in rosylated SNO-Drp1 and SNO-Cdk5 generated in response to exposure to $250 \mathrm{~nm}$ scrambled $A \beta_{1-42}$ or $250 \mathrm{~nm}$ oligomeric $A \beta_{1-42}$ in cells after pharmacological isolation of eNMDARs. Bottom lanes represent the loading control.

neurons. We observed dramatic increases in the rate of NO production upon exposure to oligomeric (but not monomeric or scrambled) $\mathrm{A} \beta$, which is consistent with the currently held notion that $\mathrm{A} \beta$ oligomers contribute to neurotoxicity.

A number of studies have suggested that $A \beta$ oligomers perturb calcium homeostasis in neurons (Bezprozvanny and Mattson, 2008), in part by affecting the activity of calciumpermeable ion channels. Here, we found that oligomeric $\mathrm{A} \beta$ induced potentiation of $\mathrm{NO}$ production in cortical neurons could be blocked by specific antagonists of calcium-permeable NMDARs, including memantine, a Food and Drug Administrationapproved drug for the treatment of AD (Parsons et al., 1999; Lipton, 2006). These results connect $\mathrm{A} \beta$ oligomers, NMDARs, and NO to a unified pathway, and suggest that NMDARs mediate oligomeric $\mathrm{A} \beta$ effects, at least in part, by enhancing nNOS activity, leading to the overproduction of $\mathrm{NO}$ and subsequent nitrosative stress in neurons.

Neuronal NMDARs are found in both synaptic and extrasynaptic locations. Recent studies on models of ischemic brain injury have suggested that eNMDAR activity inhibits neuroprotective pathways and triggers neuronal injury, while physiological sNMDAR activity, in general, stimulates neuroprotective transcriptional and antioxidant pathways (Hardingham and Bading, 2010, but see Wroge et al., 2012). A similar pattern is emerging for several neurodegenerative disorders such as Huntington's disease (Okamoto et al., 2009; Milnerwood et al., 2010; Kaufman et al., 2012) and AD (Bordji et al., 2010; Li et al., 2011; Talantova et al., 2013). Here, we investigated whether this pattern holds true for neuronal NO production after exposure to $\mathrm{A} \beta$ oligomers. Using 
pharmacological isolation of eNMDARs, we determined that the production of the majority $(\sim 75 \%)$ of $\mathrm{NO}$ in cerebrocortical neurons induced by exposure to $\mathrm{A} \beta$ oligomers was mediated by activation of eNMDARs. Numerous studies have shown that 20$50 \%$ of NMDARs are extrasynaptic at 2 weeks in vitro (Petralia et al., 2010). Based on this, we estimate that eNMDARs are 3-12 times more efficient than sNMDARs in stimulating the activity of nNOS in response to an $A \beta$ insult. What could be the cause and consequence of such a dramatic difference?

sNMDAR versus eNMDAR activation usually occurs under different circumstances. sNMDARs are activated by glutamate released during phasic synaptic events, resulting in burst-like calcium influx. In contrast, eNMDARs may be activated by glutamate spillover from synapses or from ectopic release of glutamate from glial cells, resulting in continuously elevated calcium from tonic activation. In $\mathrm{AD}, \mathrm{A} \beta$ has been reported to cause increased neuronal glutamate release and decreased reuptake with consequent spillover (Abramov et al., 2009; Li et al., 2011), which could explain enhanced activation of eNMDARs. Additionally, oligomeric $\mathrm{A} \beta_{1-42}$ was recently shown to trigger release of glutamate from astrocytes, in turn stimulating contiguous neuronal eNMDARs (Talantova et al., 2013). Moreover, since synaptic activity is impaired in $\mathrm{AD}, \mathrm{sNMDARs}$ are less active under these pathological conditions (Palop and Mucke, 2010). Hence, decreased sNMDAR and increased eNMDAR activity may result in $\mathrm{AD}$ leading to preferential triggering of intracellular pathways associated with eNMDARs.

Numerous studies have demonstrated that NMDARs form complexes with various intracellular proteins, including nNOS, via scaffolding proteins such as PSD-95 and SAP102 (Christopherson et al., 1999; Sattler et al., 1999), ostensibly to ensure that local signaling via NMDARs will have a powerful impact on local NO production. Although NO production was previously thought to localize to synapses due to the location of sNMDAR/ PSD-95/nNOS complexes there, the existence of eNMDAR/ PSD-95 complexes (Petralia et al., 2010) indicates that nNOS is most likely physically associated with extrasynaptic receptors as well. Given the pattern of pathological glutamate receptor stimulation in $\mathrm{AD}$ discussed above, these physical constraints suggest that tonic activation of eNMDARs would give rise to excessive increases in NO, whereas lower levels of NO involved in synaptic signaling would be generated via phasic stimulation of sNMDARs. Indeed, this is exactly what we observed in the current study, with the predominant effect of eNMDARs over sNMDARs underlying $\mathrm{A} \beta$-induced increases in neuronal $\mathrm{NO}$ levels and downstream protein S-nitrosylation.

In summary, under normal physiological conditions, excitatory neurotransmission via sNMDARs is essential for synaptic development and plasticity as well as learning and memory. During $\mathrm{AD}$, exposure to oligomeric $\mathrm{A} \beta$ leads to a shift in the activity of two different populations of NMDARs with a decrease in sNMDAR stimulation related to progressive synaptic loss and an increase in eNMDAR stimulation due to tonic activation. The redistribution of calcium fluxes would lead to preferential activation of nNOS associated with eNMDARs, and subsequent engagement of intracellular signaling pathways that injure synapses and are proapoptotic in nature. Previous studies have established that oligomeric $\mathrm{A} \beta$ can lead to tau phosphorylation, caspase- 3 activation, and NO-mediated events, contributing to synaptic damage in AD (Roberson et al., 2007; Cho et al., 2009; Ittner et al., 2010; D'Amelio et al., 2011; Qu et al., 2011). Recently, we demonstrated that tau phosphorylation and caspase- 3 activation are mediated preferentially by $\mathrm{A} \beta$-induced $\mathrm{NMDAR}$ over
sNMDAR activity (Talantova et al., 2013). Extending these prior reports, the present study shows that $\mathrm{A} \beta$-evoked S-nitrosylation of Drp1 and Cdk5 can occur largely via eNMDAR-mediated increases in NO levels. Thus, we highlight the potential pathological role of eNMDARs in triggering the excessive NO that contributes to these downstream events, and we suggest that neuroprotection in $\mathrm{AD}$ may be achieved by specific eNMDAR antagonists that block this location-specific glutamate synaptic damage and neurotoxicity.

\section{References}

Abramov E, Dolev I, Fogel H, Ciccotosto GD, Ruff E, Slutsky I (2009) Amyloid- $\beta$ as a positive endogenous regulator of release probability at hippocampal synapses. Nat Neurosci 12:1567-1576. CrossRef Medline

Bezprozvanny I, Mattson MP (2008) Neuronal calcium mishandling and the pathogenesis of Alzheimer's disease. Trends Neurosci 31:454-463. CrossRef Medline

Bordji K, Becerril-Ortega J, Nicole O, Buisson A (2010) Activation of extrasynaptic, but not synaptic, NMDA receptors modifies amyloid precursor protein expression pattern and increases amyloid- $\beta$ production. J Neurosci 30:15927-15942. CrossRef Medline

Butterfield DA, Drake J, Pocernich C, Castegna A (2001) Evidence of oxidative damage in Alzheimer's disease brain: central role for amyloid $\beta$-peptide. Trends Mol Med 7:548-554. CrossRef Medline

Cho DH, Nakamura T, Fang J, Cieplak P, Godzik A, Gu Z, Lipton SA (2009) S-Nitrosylation of Drp1 mediates $\beta$-amyloid-related mitochondrial fission and neuronal injury. Science 324:102-105. CrossRef Medline

Choi YB, Tenneti L, Le DA, Ortiz J, Bai G, Chen HS, Lipton SA (2000) Molecular basis of NMDA receptor-coupled ion channel modulation by S-nitrosylation. Nat Neurosci 3:15-21. CrossRef Medline

Christopherson KS, Hillier BJ, Lim WA, Bredt DS (1999) PSD-95 assembles a ternary complex with the N-methyl-d-aspartic acid receptor and a bivalent neuronal NO synthase PDZ domain. J Biol Chem 274:2746727473. CrossRef Medline

D’Amelio M, Cavallucci V, Middei S, Marchetti C, Pacioni S, Ferri A, Diamantini A, De Zio D, Carrara P, Battistini L, Moreno S, Bacci A, Ammassari-Teule M, Marie H, Cecconi F (2011) Caspase-3 triggers early synaptic dysfunction in a mouse model of Alzheimer's disease. Nat Neurosci 14:69-76. CrossRef Medline

Dawson VL, Dawson TM, London ED, Bredt DS, Snyder SH (1991) Nitric oxide mediates glutamate neurotoxicity in primary cortical cultures. Proc Natl Acad Sci U S A 88:6368-6371. CrossRef Medline

Groves JT, Wang CC (2000) Nitric oxide synthase: models and mechanisms. Curr Opin Chem Biol 4:687-695. CrossRef Medline

Hardingham GE, Bading H (2010) Synaptic versus extrasynaptic NMDA receptor signalling: implications for neurodegenerative disorders. Nat Rev Neurosci 11:682-696. CrossRef Medline

Hardingham GE, Fukunaga Y, Bading H (2002) Extrasynaptic NMDARs oppose synaptic NMDARs by triggering CREB shut-off and cell death pathways. Nat Neurosci 5:405-414. CrossRef Medline

Hess DT, Matsumoto A, Kim SO, Marshall HE, Stamler JS (2005) Protein S-nitrosylation: purview and parameters. Nat Rev Mol Cell Biol 6:150 166. CrossRef Medline

Ittner LM, Ke YD, Delerue F, Bi M, Gladbach A, van Eersel J, Wölfing H, Chieng BC, Christie MJ, Napier IA, Eckert A, Staufenbiel M, Hardeman E, Götz J (2010) Dendritic function of tau mediates amyloid- $\beta$ toxicity in Alzheimer's disease mouse models. Cell 142:387-397. CrossRef Medline

Ivanov A, Pellegrino C, Rama S, Dumalska I, Salyha Y, Ben-Ari Y, Medina I (2006) Opposing role of synaptic and extrasynaptic NMDA receptors in regulation of the extracellular signal-regulated kinases (ERK) activity in cultured rat hippocampal neurons. J Physiol 572:789-798. CrossRef Medline

Jaffrey SR, Erdjument-Bromage H, Ferris CD, Tempst P, Snyder SH (2001) Protein S-nitrosylation: a physiological signal for neuronal nitric oxide. Nat Cell Biol 3:193-197. CrossRef Medline

Kaufman AM, Milnerwood AJ, Sepers MD, Coquinco A, She K, Wang L, Lee H, Craig AM, Cynader M, Raymond LA (2012) Opposing roles of synaptic and extrasynaptic NMDA receptor signaling in cultured striatal and cortical neurons. J Neurosci 32:3992-4003. CrossRef Medline

Keil U, Bonert A, Marques CA, Scherping I, Weyermann J, Strosznajder JB, Müller-Spahn F, Haass C, Czech C, Pradier L, Müller WE, Eckert A 
(2004) Amyloid $\beta$-induced changes in nitric oxide production and mitochondrial activity lead to apoptosis. J Biol Chem 279:50310-50320. CrossRef Medline

Lau A, Tymianski M (2010) Glutamate receptors, neurotoxicity and neurodegeneration. Pflügers Archiv 460:525-542. CrossRef Medline

Li S, Jin M, Koeglsperger T, Shepardson NE, Shankar G, Selkoe DJ (2011) Soluble $A \beta$ oligomers inhibit long-term potentiation through a mechanism involving excessive activation of extrasynaptic NR2B-containing NMDA receptors. J Neurosci 31:6627-6638. CrossRef Medline

Lipton SA (2006) Paradigm shift in neuroprotection by NMDA receptor blockade: memantine and beyond. Nat Rev Drug Discov 5:160-170. CrossRef Medline

Lipton SA, Choi YB, Pan ZH, Lei SZ, Chen HS, Sucher NJ, Loscalzo J, Singel DJ, Stamler JS (1993) A redox-based mechanism for the neuroprotective and neurodestructive effects of nitric oxide and related nitrosocompounds. Nature 364:626-632. CrossRef Medline

Mangialasche F, Polidori MC, Monastero R, Ercolani S, Camarda C, Cecchetti R, Mecocci P (2009) Biomarkers of oxidative and nitrosative damage in Alzheimer's disease and mild cognitive impairment. Ageing Res Rev 8:285-305. CrossRef Medline

Milnerwood AJ, Gladding CM, Pouladi MA, Kaufman AM, Hines RM, Boyd JD, Ko RW, Vasuta OC, Graham RK, Hayden MR, Murphy TH, Raymond LA (2010) Early increase in extrasynaptic NMDA receptor signaling and expression contributes to phenotype onset in Huntington's disease mice. Neuron 65:178-190. CrossRef Medline

Nakamura T, Tu S, Akhtar MW, Sunico CR, Okamoto S, Lipton SA (2013) Aberrant protein S-nitrosylation in neurodegenerative diseases. Neuron 78:596-614. CrossRef Medline

Okamoto S, Pouladi MA, Talantova M, Yao D, Xia P, Ehrnhoefer DE, Zaidi R, Clemente A, Kaul M, Graham RK, Zhang D, Vincent Chen HS, Tong G, Hayden MR, Lipton SA (2009) Balance between synaptic versus extrasynaptic NMDA receptor activity influences inclusions and neurotoxicity of mutant huntingtin. Nat Med 15:1407-1413. CrossRef Medline

Palop JJ, Mucke L (2010) Amyloid- $\beta$-induced neuronal dysfunction in Alzheimer's disease: from synapses toward neural networks. Nat Neurosci 13:812-818. CrossRef Medline

Papadia S, Soriano FX, Léveillé F, Martel MA, Dakin KA, Hansen HH, Kaindl A, Sifringer M, Fowler J, Stefovska V, McKenzie G, Craigon M, Corriveau R, Ghazal P, Horsburgh K, Yankner BA, Wyllie DJ, Ikonomidou C, Hard- ingham GE (2008) Synaptic NMDA receptor activity boosts intrinsic antioxidant defenses. Nat Neurosci 11:476-487. CrossRef Medline

Parsons CG, Danysz W, Quack G (1999) Memantine is a clinically well tolerated $\mathrm{N}$-methyl-d-aspartate (NMDA) receptor antagonist-a review of preclinical data. Neuropharmacology 38:735-767. CrossRef Medline

Petralia RS, Wang YX, Hua F, Yi Z, Zhou A, Ge L, Stephenson FA, Wenthold RJ (2010) Organization of NMDA receptors at extrasynaptic locations. Neuroscience 167:68-87. CrossRef Medline

Qu J, Nakamura T, Cao G, Holland EA, McKercher SR, Lipton SA (2011) S-Nitrosylation activates Cdk5 and contributes to synaptic spine loss induced by $\beta$-amyloid peptide. Proc Natl Acad Sci U S A 108:14330-14335. CrossRef Medline

Roberson ED, Scearce-Levie K, Palop JJ, Yan F, Cheng IH, Wu T, Gerstein H, Yu GQ, Mucke L (2007) Reducing endogenous tau ameliorates amyloid $\beta$-induced deficits in an Alzheimer's disease mouse model. Science 316: 750-754. CrossRef Medline

Sattler R, Xiong Z, Lu WY, Hafner M, MacDonald JF, Tymianski M (1999) Specific coupling of NMDA receptor activation to nitric oxide neurotoxicity by PSD-95 protein. Science 284:1845-1848. CrossRef Medline

Selkoe DJ (2002) Alzheimer's disease is a synaptic failure. Science 298:789791. CrossRef Medline

Stark DT, Bazan NG (2011) Synaptic and extrasynaptic NMDA receptors differentially modulate neuronal cyclooxygenase- 2 function, lipid peroxidation, and neuroprotection. J Neurosci 31:13710-13721. CrossRef Medline

Tackenberg C, Grinschgl S, Trutzel A, Santuccione AC, Frey MC, Konietzko U, Grimm J, Brandt R, Nitsch RM (2013) NMDA receptor subunit composition determines beta-amyloid-induced neurodegeneration and synaptic loss. Cell Death Dis 4:e608. CrossRef Medline

Talantova M, Sanz-Blasco S, Zhang X, Xia P, Akhtar MW, Okamoto S, Dziewczapolski G, Nakamura T, Cao G, Pratt AE, Kang YJ, Tu S, Molokanova E, McKercher SR, Hires SA, Sason H, Stouffer DG, Buczynski MW, Solomon JP, Michael S, et al (2013) A $\beta$ induces astrocytic glutamate release, extrasynaptic NMDA receptor activation, and synaptic loss. Proc Natl Acad Sci U S A 110:E2518-27. CrossRef Medline

Wroge CM, Hogins J, Eisenman L, Mennerick S (2012) Synaptic NMDA receptors mediate hypoxic excitotoxic death. J Neurosci 32:6732-6742. CrossRef Medline 